DOI: $10.2478 / \mathrm{v} 10249-011-0029-5$

\title{
Optical properties of the human skin
}

\author{
Zorica GAJINOV ${ }^{*}$, Milan MATIĆ ${ }^{1}$, Sonja PRĆIĆ , Verica ĐURAN¹. \\ ${ }^{1}$ Institute of Child and Youth Health Care of Vojvodina, Novi Sad, Serbia \\ ${ }^{2}$ Clinic of Dermatovenereology Diseases, Clinical Center of Vojvodina, Novi Sad, Serbia \\ ${ }^{*}$ Correspondence: Zora Gajinov, E-mail: gajinovz@uns.ac.rs
}

UDC 612.38:612.84

\begin{abstract}
Visual perception of human skin is determined by the light that reflects off the skin surface to retina and interpretation of these information by visual centers in the brain cortex. Skin has a partly translucent and turbid structure and visual perceptions depend on interactions between the light and structures of the skin surface and below it, through absorption, reflection and scattering. Light absorption by the skin depends on the composition, absorption spectra and amount (volume fraction) of chromophores. Subsurface scattering occurs within the skin layers: Rayleigh scattering (subcellular structures sized up to $1 / 10$ of incident wavelength) and Mie scattering (collagen, melanosomes). Due to fluctuations of the refractive index within tissue components and intense scattering, the spatial distribution of light within the skin is diffuse. Skin images are created by the light that reflects off the skin after being color-modified by absorption and being scattered on the skin surface and internal skin structures.
\end{abstract}

\section{Key words}

Skin; Skin Absorption; Light; Optical Processes; Sunlight

$\mathrm{O}$ ur perception of human skin is determined by the visible light that reflects off the skin surface to retina and interpretation of these information by visual centers in the brain cortex. Skin is partly a translucent medium, similar to various natural (ice, marble, wax, plant leaves) and artificial materials (plastics), and important visual information depend on interactions between the light and structures below the skin surface. That complexity of human skin makes painting realistic portraits a demanding artistic task. Optical properties which determine the skin appearance may be summarized through the process interaction between the light and the skin tissues absorption, reflection and scattering.

\section{Interaction between the skin and visible light}

Visible light energy interacts with the skin by: absorption (chromophores absorb photon energy and transform it into heat), elastic scattering (light changes its path due to differences in refraction index within the skin), fluorescence (incident photons induce electron conversion into molecule, followed by emission of a photon of lower energy and longer wavelength) and inelastic scattering (photons lose energy to vibrational states followed by emission of lower energy photons of longer wavelength). Absorption and elastic scattering are the most prevalent interactions. Fluorescence occurs frequently, but with 10-100 times lower intensities.

High-power light sources of visible wavelengths (lasers with femtosecond pulses) may induce nonlinear processes (two-photon conversion, second harmonic generation) but these are not visible to the human eye, and require complex instruments to be analyzed.

Skin images humans see (by naked eye, photography ...), called diffuse reflectance images, are created by the light that reflects off the skin after being color-modified by absorption and being scattered on the skin surface and internal skin structures (1-3). 


\section{Absorption}

Light absorption in the skin depends on the composition and amount of chromophores. Corneal layer is thin, corneal absorption within it is minimal, and transmission of light to deeper epidermal layers is uniform. In viable epidermis, a melanin is a natural light-absorbing chromophore, with broad absorption spectra (being the most intensive in the ultraviolet spectrum and shorter wavelengths). The intensity of absorption (mathematical term of epidermal absorption coefficient) directly depends on the volume fraction of epidermis that is occupied by melanosomes $(1.3-43 \%)$. Jacques et al. reported that the volume fraction of melanin in the epidermis is 1 to $3 \%$ for light-skinned Caucasians, 11 to $16 \%$ for Mediterranean types, and $18-43 \%$ for darkly pigmented Africans $(4,5)$.

The dermis consists of two layers network of connective tissue fibers, and blood vessels. Hemoglobin is the main dermal chromophore. Absorption of both oxyhemoglobin and deoxy-hemoglobin have absorption peaks in blue $(400-420 \mu \mathrm{m})$, and greenyellow range (540-577 $\mu \mathrm{m})$, and decrease gradually for longer wavelengths. Deoxy-hemoglobin has its highest absorption peak at $420 \mu \mathrm{m}$, and a second peak at 580 $\mu \mathrm{m}$. Oxy-hemoglobin shows its highest absorption peak at $410 \mu \mathrm{m}$, and two secondary peaks at 550 $600 \mu \mathrm{m}$ range. The intensity of absoprtion directly depends on the volume fraction of tissue occupied by hemoglobin $(0.2-7 \%)$. The blood volume fraction in the cutaneous blood content (in the superficial plexus about $100-200 \mu \mathrm{m}$ from the surface) is about $2-5 \%$, while in other parts of the dermis the volume fraction is much lower $(2,6)$.

Other blood derived pigments, bilirubin and carotenoids, are responsible for yellowish and olive hue in basic skin tan. Beta-carotene and lycopene have absorption peaks at 488 and $515 \mu \mathrm{m}$, and bilirubin at $460 \mu \mathrm{m}(7)$.

Absorption of visible light in subcutis is neglible; considering the white color of adipose tissue, most of the light that reaches the subcutis is reemitted into the dermis (6).

Light absorption by other skin structures is not contributing to visual appearance, due to absorption maxima being out of the visual spectrum. Epidermal nucleic acids (peak at $260 \mu \mathrm{m}$ ), urocanic acid (peak at $277 \mu \mathrm{m}$ ), keratin (peak approximately at $280 \mu \mathrm{m}$ ) absorb UV radiation. Water is absorbed in the infrared spectrum (peak approximately at $980 \mu \mathrm{m}$ ) and the thermal effect is mediated by water content of tissues. Dermal proteins are absorbed near UV, collagen in the visible and near the infra-red spectra.

\section{Coefficient of absorption}

Absorption coefficient of the human skin (determined in vivo) is wavelength dependent, and in agreement with in-vitro determined values for various chromophores. Maximal absorption coefficient is at around $500 \mu \mathrm{m}$, with a twofold decrease if wavelengths increase from 500 to $600 \mu \mathrm{m}$, and it corresponds to melanin and hemoglobin absorption maxima in this region. With further wavelength increase, from 600 to $800 \mu \mathrm{m}$, the absorption coefficient decreases smoothly. The absorption spectra of darker skin types (Fitzpatrick's V-VI types) have a greater slope in the visual wavelength region, compared to lighter skin types (I-II and III-IV), being the consequence of differences in melanin concentrations in various skin types, assuming other chromophore concentrations are similar. At wavelengths longer than $900 \mathrm{~nm}$ (infrared spectra), the absorption coefficients of three skin type groups have almost the same magnitude and a characteristic prominent absorption peak induced by water absorption at $980 \mu \mathrm{m}(8)$. In conclusion, at wavelengths shorter than $600 \mu \mathrm{m}$, absorption by melanin and hemoglobin is dominant, while at 600$800 \mu \mathrm{m}$, the reflectance spectral features are mainly affected by scattering.

\section{Reflection}

Reflection of light on the skin surface occurs on the account of differences in refraction indices between the air $(1,0)$ and the corneal layer $(1,45)$. Fresnel's equation illustrates proportions of light that is reflected and refracted (transmitted towards deeper layers) on air-skin interface, as functions of incident angle of light and refraction indices of medium from which the light beam approaches the skin (air usually) and medium that further transmits the light (incident and transmissive medium). When the incident angle is close to normal $\left(<40^{\circ}\right)$ about $5 \%$ of light is directly reflected from the corneal layer surface, and the rest 95\% enters the epidermis. The reflected light is not 
interacted with the interior of the skin and is not color-modified by skin chromophores. The increase of the incident angle of light increases the amount of light reflected from the skin surface. Presence of sebum smoothes the roughness of the skin surface, and due to the fact that a higher refractive index (1.5) increases the amount of light reflected off the air-sebum interface, it accentuates the appearance of shine (9).

\section{Scattering}

Scattering is a dominant type of interaction of visible and near infra-red light spectra with tissues, being 100-1000 times stronger than absorption (10). Scattering is a deflection of light beams from a straight trajectory caused by microscopic non-uniformities in the medium through which the light passes (scattering particles), and fluctuations of refractive index. Type and intensity of scattering depends on the size of the scattering particles in relation to the wavelength of the incoming light.

\section{Elastic scattering}

Elastic scattering refers to processes where photons of incident and scattered light have the same energy (wavelength), whereas Rayleigh and Mie models of elastic scattering are applied for light scattering in tissues.

Rayleigh scattering occurs on particles much smaller than incident wavelength (up to $1 / 10$ of incident wavelength size). Oscillating electromagnetic field of incident radiation induces the electron distribution of a molecule (scattering particle) to oscillate, inducing point dipole in the molecule, while light is scattered uniformly in all directions. According to Rayleigh theory, scattering probability is inversely proportional to the fourth power of the wavelength of the scattered light, therefore shorter wavelengths are scattered more efficiently than longer wavelengths.

Mie scattering occurs when the scattering particles are of similar size as the wavelength of light. These large particles do not act as dipoles, and intraparticle interference causes an angular dependent scattering pattern. It depends on particle size and shape (spherical particles); the intensity of forward scattering (in the same direction as the incident light) is in correlation with these parameters.
Illustrative didactic examples for $\mathrm{Mie}$ and Rayleigh scattering are optical phenomena in atmosphere: Rayleigh scattering is responsible for blue sky (shorter blue wavelengths are scattered more efficiently by small particles in the air than longer wavelengths), and Mie scattering for white color of clouds (due to water droplets) $(11,12)$.

\section{Surface and subsurface scattering of light in the skin}

In human skin, scattering has two mayor components: surface and subsurface scattering. Surface scattering is influenced by irregularities in the corneal layer (wrinkles, skin dehydration), and it is similar to reflection.

Subsurface scattering within the skin occurs in cell membranes and corpuscles, keratohyaline granules, melanosomes, cellular organelle, mitochondria, nuclei, extracellular lipid droplets, protein aggregates, and collagen fibers. Corneal layer and epidermis are characterized as forward scattering media, due to the orientation of keratin fibrils and Mie scattering in cellular structures of similar size and wavelength (organelle, melanosomes) (13). Large cylindrical collagen fibers in the reticular dermis are responsible for Mie scattering that is directed forward, while Rayleigh scattering occurs on smaller collagen fibrils in papillary dermis and other microstructures. Light is scattered many times within the dermis, until finally being absorbed or transmitted to the next layer, which means that spatial distribution of light scattered within the dermis soon becomes diffuse, and tissues with intense scattering seem turbid $(14,15)$.

\section{Light scatterers in the skin}

Parameters that affect the scattering properties of tissues are tissue morphology (size of organelles and cells in relation to the wavelength of incident light, which affect the angular distribution of the scattered light), and biochemistry (refraction index is determined by biochemical characteristics of tissues). Great differences in the refractive index of a cell component and its surrounding will result in increased scattering (binary fluctuation of refractive index).

The matter surrounding the scatterers (intercellular liquid and cytoplasm, ground substance) is composed mainly of water with salts and organic components, and the refractive index is 1.35-1.37. 
The scattering particles (organelles, protein fibrils, membranes, protein globules) have a higher density of proteins and lipids in comparison with the ground substance and thus a greater index of refraction (1.391.47).

Collagen fibers are the main scatterers in the stroma; due to their fibrilar structure, high refractive index (axial 1.32-1,45, radial 1.40-1.61), scattering in the stroma is much more abundant than in the epithelial layers $(3,17)$.

Melanin has a high index of refraction (1.7) compared with the surrounding cell components; the size of melanosomes is $100 \mu \mathrm{m}-1000 \mu \mathrm{m}$. Large increase in melanin scattering has been observed in vitro (18), but in vivo, no significant differences have been detected between scattering properties of melanocytic nevus and healthy skin. This suggests that the primary optical function of melanin is absorption, and that Rayleigh scattering in melanin is negligible in comparison with melanin absorption and scattering in other microstructures of the skin (19).

\section{Penetration of human skin by visible light}

Visible light $(400-760 \mu \mathrm{m})$ goes through intense absorption and scattering within the skin, and that attenuation of incident light is limiting the depth to which visible radiation may penetrate. At wavelengths shorter than $600 \mathrm{~nm}$, light absorption by hemoglobin and melanin is dominant, while skin scattering is attributed to small Rayleigh scatterers, such as melanin dust and structural cell components, much smaller $(<300 \mu \mathrm{m})$ than the wavelength. At visible wavelengths, longer than $600 \mu \mathrm{m}$, absorption decreases; Mie scattering occurs on large collagen and elastin bundles, sized several $\mu \mathrm{m}$, being intensely directed forward (following the direction of incident light towards deeper skin layers) $(20,8)$. With longer wavelengths (700 to $1300 \mu \mathrm{m})$ scattering in the skin decreases; due to low scattering these wavelengths have the greatest penetration depth into the skin, and are referred to as the optical window. Light of longer wavelength is absorbed by water and does not penetrate deeply into skin.

The penetration depth of light into the skin is defined as the depth at which the incident intensity is attenuated to a certain level outside the skin; it is an indication of the rate at which the intensity of the incident light is attenuated in the tissue $(1,21)$.

\section{Polarized light scattering in the skin}

Scattered light carries important information about the morphology of tissues. Upon scattering, distribution and direction of light changes, and methods using polarized light can more precisely determine scattering characteristics of the medium. Optical activity of molecules determines the speed and level of polarized light randomization. Dermal collagen has a property of birefringence (double refraction of polarized light), dependent on orientation of fibers in relation to vectors of polarization of incident light, and both birefringent and the scattering effects can change the polarization state of light. Information about the structure of a tissue and the birefringence of its components can be extracted from the registered depolarization degree of initially polarized light. Polarization properties of light reflected from tissues can be used as a selector of photons coming from different depths in the tissue. Such polarization gating can provide novel contrast mechanisms for tissue imaging and spectroscopy (2224). Human eye is not sensitive to the polarization characteristics of light, therefore complex instruments are necessary for such precise measurements.

\section{Light passing through the skin}

Pathway of light through the skin is presented in Figure 1 . On the surface of the corneal layer $4-7 \%$ of light is being reflected; the remaining light enters and traverses the corneal layer, being scattered only by degraded melanosomes (melanin dust) in flattened corneal cells. The light then enters the viable epidermis where it is absorbed and scattered by the epidermal melanin pigment. The direction of travel of the light is changed whenever a change in the index of refraction occurs in its path of travel. Cell membranes and organelles have slightly different indices of refraction than the bulk index of the epidermis, and therefore cause slight changes in the direction of travel through the corneal layer; due to scattering in the epidermal layers, it is directed forward into dermis. A proportion of light is absorbed by melanin, in correlation with the volume fraction of tissue occupied by melanosomes. Upon entering the dermis, light is scattered due to Rayleigh scattering in small collagen fibrils in the 


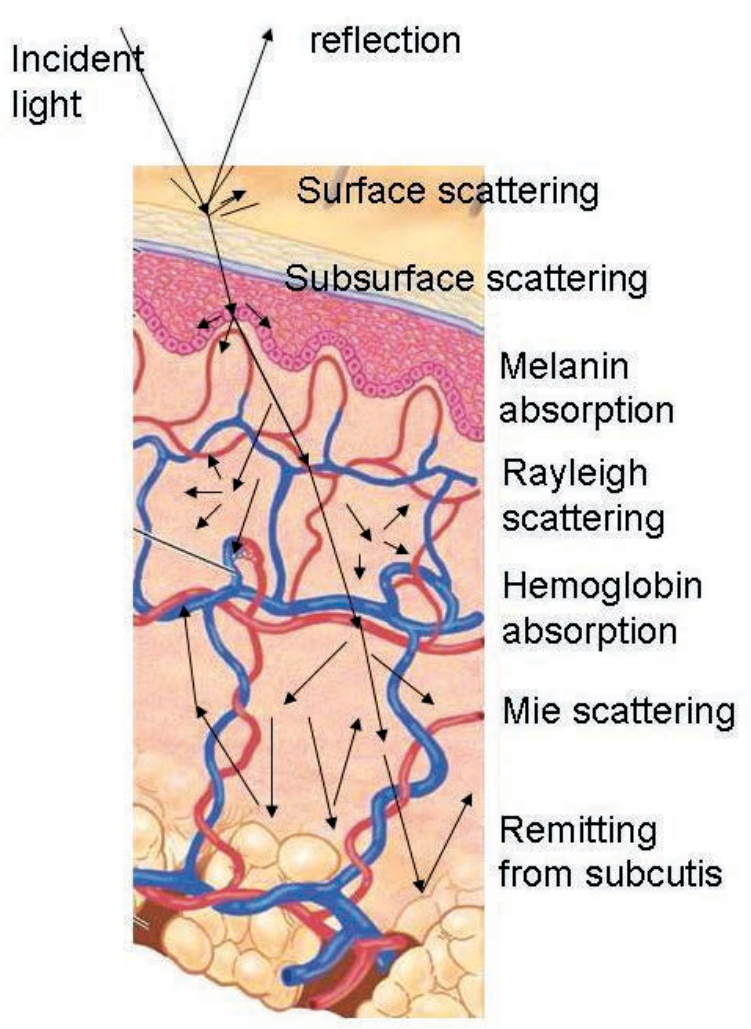

Figure 1. Optical pathway of visible light through the skin

papillary dermis, while light scattered backward enters epidermis again, scatters preferentially towards the surface of the skin and out of it. Upon entering reticular dermis the light scatters in larger collagen fibers (Mie scattering) directing forward to deeper layers, subcutis. Therefore, light reemitted from the reticular layer is thus considered negligible due to the highly forward-directed Mie scattering. A proportion of light in dermis is absorbed by hemoglobin, proportionally to its volume fraction in the tissue.

Upon Mie scattering, light in reticular dermis reaches subcutis and is largely reemitted back and then traverses the hemoglobin and melanin filter and after that it is again reflected and scattered by the air interface out of the skin. The light we detect (photograph) has traveled twice through the melanin and the hemoglobin filters.

\section{Conclusion}

When describing the state of skin we need to characterize the surface features (contours, scars, fine texture, surface appearance) as well as the subsurface features (erythema, pigmentation and dermal collagen scattering) that contribute to the appearance of the skin (25). Understanding and modeling optical properties of the skin is a dynamic field of investigation, driven by various medical and industrial needs (diagnostic or photo-therapeutic use in medicine, cosmetic science, entertainment industry, computer graphics, computer vision etc.). Skin has irregular morphology, with follicles and glands, layered structures, and exhibits anisotropic behavior. Therefore all models of light interaction with the skin are simplified, only representing some important features. More comprehensive models of skin optics are still necessary.

\section{Refrences}

1. Kollias N. The interaction of light with the skin. In: Wilhelm K, Elsner P, Berardesca E, Maibach H, editors, Bioengineering of the skin: skin imaging and analysis. 2nd ed. New York: Informa Healthcare; 2007. p. 222-8.

2. Anderson R, Parrish JA. The optics of human skin. J Invest Dermatol 1981;77:13-9

3. Igarashi T, Nishino K, Nayar SK. The appearance of human skin. Technical Report: CUCS-024-05 [cited 21.01.2011.] Available at http://citeseerx.ist.psu.edu/viewdoc/ download?doi=10.1.1.87. 5961 \& rep=rep1\&type =pdf

4. Jacques S, Glickman R, Schwartz J. Internal absorption coefficient and threshold for pulsed laser disruption of melanosomes isolated from retinal pigment epithelium. SPIE Proc 1996;2681:468-77

5. Jacques SL. Skin optics. Oregon Medical Laser Center News Jan 1998. [cited 08.02.2011.] Available at: http://omlc.ogi.edu/ news/jan98/skinoptics.htmlhttp://omlc.ogi.edu/news/jan98/ skinoptins.html

6. Baranoski GV, Krishnaswamy A. An introduction to light interaction with human skin. RITA 2004; XI:33-62. [cited 08.02.2011.] Available at http://www.seer.ufrgs.br/rita/article/ view/rita_v11_n1_p33-62/3553

7. Darvin ME, Gersonde I, Albrecht H, Gonchukov SA, Sterry W, Lademann J. Determination of beta carotene and lycopene concentrations in human skin using resonance raman spectroscopy. Laser Physics 2005;15(2):295-9.

8. Tseng SH, Bargo P, Durkin A, Kollias N. Chromophore concentrations, absorption and scattering properties of human skin in-vivo. Optics Express 2009;17:14599-617.

9. Li L, Soling C. A physically-based human skin reflection model. Proceedings of the 10th WSEAS International Conference on Automation \& Information; 2009 March 23-25; Prague, Czech Republic. Wisconsin: WSEAS; 2009. p. 25-30.

10. Cheong WF, Prahl SA, Welch AJ. A review of the optical properties of biological tissues. IEEE J Quantum Electron 1990;26:2166-85

11. Pecina MA, Smith CA. A classroom demonstration of rayleigh light scattering in optically active and inactive systems. J Chem Educ 1999;76(9):1230-3 
12. Nave R. Hyperphysics: Blue Sky and Rayleigh scattering. [cited 08.02.2011.] Available at http://hyperphysics.phyastr.gsu. edu/Hbase/atmos/blusky.html

13. Bruls WAG, Van der Luen JC. Forward scattering properties of human epidermal layers. Photochem. Photobiol 1984;40:23142.

14. Krishnaswamy A, Baranoski GVG. A study on skin optics. Natural phenomena simulation Group, School of computer science, University of Waterloo, Canada. Technical Report CS2004-01, January, 2004. Available at http://www.cs.uwaterloo. $\mathrm{ca} /$ research/tr/2004/01/tech-rep-CS-2004-01.pdf

15. Krishnaswamy A. Baranoski GVG. A biopysicallybased spectral model of light Interaction with human skin. Eurographics 2004;23:331-40.

16. Saidi I, Jacques S, Tittel F. Mie and Rayleigh modeling of visible light scattering in neonatal skin. Appl Optom 1995;34:7410-8.

17. Arifler D, Pavlova I, Gillenwater A, Richards-Kortum R. Light scattering from collagen fiber networks: microoptical properties of normal and neoplastic stroma. Biophys J 2007;92:3260-74.
18. Dunn A, Richards-Kortum R. Three-dimensional computation of light scattering from cells. IEEE J Sel Topics Quantum Electron 1996;2(4):898-905.

19. Zonios G, Dimou A. Light scattering spectroscopy of human skin in vivo. Optics Express 2009; 17:1256-67.

20. Bashkatov AN, Genina EA, Kochubey VI, Tuchin VV. Optical properties of human skin, subcutaneous and mucous tissues in the wavelength range from 400 to $2000 \mathrm{~nm}$. J Phys D: Appl Phys 2005;38:2543-55.

21. Nielsen KP, Zhao L, Stamnes JJ, Stamnes K, Moan J. The optics of human skin: aspects important for human health. In: Bjertness E, ed. Solar radiation and human health. Oslo: The Norwegian Academy of Science and Letters; 2008. p. 35-46.

22. Jacques SL, Ramella-Roman J, Lee K. Imaging superficial tissues with polarized light. Lasers Surg Med 2000;26:119-29.

23. Jacques SL, Ramella-Roman J, Lee K. Imaging skin pathology with polarized light. J Biomed Optics 2002;7(3):329-40.

24. Tuchin V, Wand L, Zimnyakov V. Optical polarization in biomedical applications. Berlin: Springer-Verlag; 2006.

25. Bargo PR, Kollias N. Measurement of skin texture through polarization imaging. Br J Dermatol 2010;162:724-31.

\section{Optičke osobine ljudske kože}

\section{Sažetak}

Vizuelni utisak o ljudskoj koži potiče od vidljivog svetla, koje sa površine kože dolazi do mrežnjače oka, $\mathrm{i}$ interpretacije tih informacija u moždanim centrima za vid. Koža je delimično translucentna mutna sredina; vizuelna informacija potiče od interakcija svetla i struktura površine $\mathrm{i}$ ispod nje, putem procesa apsorpcije, refleksije i rasipanja svetlosti. Apsorpciju svetlosti u koži određuju sastav, apsorpcioni spektar i količina (volumen tkivne frakcije) hromofora. Rasipanje unutar

tkiva ima dve glavne komponente koje rasipaju svetlost po Rayleigh modelu (sitnije čestice) i Mie modelu (krupnije strukture kolagena, elastina, melanozomi). Usled velikih fluktuacija u indeksu prelamanja unutar tkiva, i intenzivnog rasipanja, prostorna distribucija svetla u koži je difuzna. Slika kože koju ljudi registruju posledica je svetlosti koja izlazi iz kože, nakon modifikacije boje (apsorpcija) i rasipanja na površini kože i strukturama unutar nje.

\section{Ključne reči}

Koža; Apsorpcija kože; Svetlo; Optički Procesi; Sunčeva svetlost 